\title{
GENETIC VARIATIONS WITHIN AND AMONG POPULATIONS OF ANASTATICA HEIROCHUNTICA AT MACROSCALE GEOGRAPHICAL RANGE
}

\author{
KABIEL, H.F. ${ }^{1}-$ HEGAZY, A.K. ${ }^{1,2} *$ - FAISAL, M. ${ }^{2}$ - DOMA, E.A. ${ }^{3}$ \\ ${ }^{1}$ Botany Department, Faculty of Science, Cairo University, Giza 12613, Egypt \\ ${ }^{2}$ Department of Botany and Microbiology, College of Science, King Saud University, Riyadh, \\ Saudi Arabia \\ ${ }^{3}$ Department of Botany, College of Arts and Science, Al Marqab University, Tripoli, Libya \\ *Corresponding author \\ e-mail: akhegazy@yahoo.com \\ (Received $9^{\text {th }}$ December 2012; accepted $2^{\text {nd }}$ September 2013)
}

\begin{abstract}
The annual plant Anastatica hierochuntica is an Ombrohydrochloric species where the seeds released from the canopy seed bank throughout several years. The genetic variations at the intra- and interpopulation levels were studied in the runnel microhabitat in Libya, Egypt and Saudi Arabia. The genetic diversity was detected by RAPD analysis of the DNA material. The amount of genetic variation within Anastatica hierochuntica populations reached $67.910 \%$ of the total variance. The Nei's gene diversity ranged from 0.336 to 0.361 and the Shannon's diversity index from 0.506 to 0.588 showing relatively high values. The highest value of the gene diversity was obtained in the Libya population. Lower values of the Nei's gene diversity were obtained in the Saudi Arabia then in the Egypt populations. Strong linear relationships were obtained between the Nei's gene diversity and the total amount of annual rainfall $\left(R^{2}=0.88\right)$ and between the differences in the total annual rainfall and the values of the fixation index between population pairs $\left(\mathrm{R}^{2}=0.83\right)$. The role of the dispersal mode in shaping the genetic variations in the species was discussed as the canopy seed bank was suggested to have great significance in the context of species evolution and conservation of genetic diversity.
\end{abstract}

Keywords: RAPD, Genetic diversity, genetic differentiation, fixation index, geographical distance

\section{Introduction}

Environmental factors and habitat heterogeneity have a great role in shaping the genetic diversity in species (Vellend and Geber, 2005). The genetic diversity in plant species has an important role in the conservation genetics and the evolution ability (Reed and Frankham, 2003). Among the possible traits that were reported to increase the genetic diversity for annual and perennial species is the presence of an efficient seed dispersal mechanism (Venable and Lawlor, 1980; Hamrick et al., 1993; Cabin et al., 1998; Ouborg et al., 1999; Honnay et al., 2008).

The annual plant Anastatica hierochuntica is a Ombrohydrochloric species where seed dispersal depends on both the presence and the amount of rainfall (Van Oudtshoorn and Van Rooyen, 1999). The presence of canopy seed bank with hygrochastic nature is an additional mechanism for seed dispersal where part of the stored seeds is released each year from the skeletons of dead plants (Friedman et al., 1978; Hegazy et al., 2006). The species is phenotypically plastic in response to the water conditions of the environment (Evenari et al., 1982; Hegazy et al., 1990; Hegazy and Kabiel, 2010). 
Anastatica hierochuntica is recorded in North Africa from Morocco to Egypt inhabiting runnels, patches and depressions microhabitats (Boulos, 1983; Hegazy and Kabiel, 2007). The species is subjected to overcollection for folk medicinal uses in North Africa where the infusion of the dry plants was reported to reduce pains, facilitates childbirth, and used as emmenagogue and for epilepsy (Boulos, 1983).

In previous studies, the population ecology of Anastatica hierochuntica was investigated concerning its demographic, productive and spatial pattern response to habitat heterogeneity (Hegazy and Kabiel, 2007; 2010). In the present study, two main questions were discussed:

(1) How genetic variations are organized at the intra- and interpopulation levels?

(2) What is the genetic response of the species to macroscale habitat heterogeneity?

Data are discussed at the intra- and interpopulation levels as well as the role of the dispersal mode in shaping the genetic variation of the species.

\section{Materials and methods}

\section{Field data}

\section{Study sites}

Populations of Anastatica hierochuntica were collected from the runnel microhabitat in Libya, Egypt and Saudi Arabia. Two subpopulations were studied in each of Libya and Saudi Arabia at Al-Watya and Thumamah respectively (Table 1). Six subpopulations were studied in Egypt, three were located in a gravel site (Wadi Hagoul, around $70 \mathrm{~km}$ east of Cairo) and the others in a sand site (Bahareya Oasis, around 300 $\mathrm{km}$ south-west of Cairo). The study site in Libya is located at elevation of $145 \mathrm{~m}$ asl, while that in Saudi Arabia is located at elevation of $591 \mathrm{~m}$ asl. Mean values of maximum and minimum temperatures and total annual rainfall are shown in Table 1. The study sites are located at $32^{\circ} 07^{\prime} 27.3^{\prime \prime} \mathrm{N}, 11^{\circ} 46^{\prime} 37.0^{\prime \prime} \mathrm{E}$ in Libya, $28^{\circ} 21^{\prime} 49.8^{\prime \prime} \mathrm{N}$, $29^{\circ} 11^{\prime} 10.3^{\prime \prime} \mathrm{E}$ (sand site) and $29^{\circ} 55^{\prime} 08.0^{\prime \prime} \mathrm{N}, 32^{\circ} 11^{\prime} 55.9^{\prime \prime} \mathrm{E}$ (gravel site) in Egypt and at $25^{\circ} 14^{\prime} 56.9^{\prime \prime} \mathrm{N}, 46^{\circ} 37^{\prime} 42.2^{\prime \prime} \mathrm{E}$ in Saudi Arabia.

Table 1. Localities and climatological parameters of the study A. hierochuntica populations

\begin{tabular}{|c|c|c|c|}
\hline Parameter & Libya & Egypt & Saudi Arabia \\
\hline Number of populations & 2 & 6 & 2 \\
\hline Elevation range ( $\mathrm{m}$ asl) & $120-145$ & $212-239$ & $591-650$ \\
\hline Total annual rainfall (mm) & 159.3 & 13.37 & 61.36 \\
\hline Mean maximum annual temperature $\left({ }^{\circ} \mathrm{C}\right)$ & 34.3 & 29.55 & 34.2 \\
\hline Mean minimum annual temperature $\left({ }^{\circ} \mathrm{C}\right)$ & 14.8 & 14.75 & 18.9 \\
\hline
\end{tabular}

\section{Greenhouse experiment}

Individuals of $A$. hierochuntica in $1 \times 1 \mathrm{~m}^{2}$ plots were collected for the estimation of the dry phytomass as a fitness trait and an indirect measure of the canopy seed bank and population size (Hegazy and Kabiel, 2010). Five plots were randomly chosen in every study site. 
Seeds from individuals belonging to each of the study subpopulations from the three countries were allowed to germinate at the green house of Cairo University (Giza, Egypt) in open air conditions in March-2011. Twenty-cm diameter pots full of sandy soil were used; five pots for each generation, and each pot contained 10 sown seeds. Irrigation $(150 \mathrm{ml}$ per pot) was performed every day during the first week then every other day after that. After the expansion of the first three green leaves, the plants were harvested for further DNA analysis.

\section{Genetic variation}

Total genomic DNA was extracted from green leaves using Wizard genomic DNA extraction kit DNase plant Qia gene. 10- to 21-mer arbitrary primers were used for RAPD analysis. Ten primers were screened for their amplification (Table 1). PCR amplification was performed in total volume of $25 \mu$ l containing $10 \times$ reaction buffer, $2.5 \mu \mathrm{ldNTPs}, 2 \mu \mathrm{l} \mathrm{MgCl} 2,3 \mu \mathrm{l} /$ reaction primer, $10 \mathrm{ng}$ of genomic DNA and $5 \mathrm{U}^{-1}$ of Taq polymerase (promega, Germany). The PCR temperature profile was applied through a Gene Amp ${ }^{\circledR}$ PCR System 9700 (Perkin Elmer, England). After a denaturation step for $5 \mathrm{~min}$ at $94{ }^{\circ} \mathrm{C}$, the amplification reactions were carried out for 40 cycles. Each cycle comprised 40 second at $94{ }^{\circ} \mathrm{C}, 1$ min of annealing temperature ranged $36{ }^{\circ} \mathrm{C}$ in the primers used and $1 \mathrm{~min}$ at $72{ }^{\circ} \mathrm{C}$. The final elongation step was extended to $7 \mathrm{~min}$. Amplification products were resolved by electrophoresis in a $1.5 \%$ agarose gel containing ethidium bromide $\left(0.5 \mu \mathrm{g} \mathrm{ml}^{-1}\right)$ in $1 \times \mathrm{TBE}$ buffer at 95 volts. PCR products were visualized on UV light and photographed using a gel documentation system (Bio$\operatorname{Rad}^{\circledR}$ Gel Doc-2000). Amplification products were compared with molecular weight marker $\mathrm{I} \times(100$ to $1000 \mathrm{bp})$. DNA analysis was performed in AGERE, Agricultural research center.

Table 2. Nucleotide sequence of RAPD primers used in the study

\begin{tabular}{c|c}
\hline Primer & Sequence (5'-3') \\
\hline B -10 & CTGCTGGGAC \\
C - 02 & GTGAGGCGTC \\
C - 15 & GACGGATCAG \\
M - 05 & GGGAACGTGT \\
M -02 & ACAACGCCTC \\
C - 19 & GTTGCCAGCC \\
M - 17 & TCAGTCCGGG \\
Q - 01 & GGGACGATGG \\
Q - 06 & GAGCGCCTTG \\
D - 01 & ACCGCGAAGG \\
\hline
\end{tabular}

\section{Data analysis}

To assemble the matrix of the RAPD phenotypes, bands were scored as binary presence (1) or absence (0) characters. The parameters of genetic diversity and differentiation, estimated are the percentage polymorphic loci $(P P L)$, observed number of alleles $(\mathrm{Na})$, number of effective alleles $\left(N_{\mathrm{e}}\right)$, Nei's gene diversity $(h)$ and Shannon's diversity index $(I)$. These parameters were calculated on the basis of gene frequencies using POPGENE 3.2 software (Yeh et al., 1997). The genetic diversity parameters were estimated for each of the three study populations. The genetic differentiation 
parameters were estimated between population pairs. The fixation index $F_{s t}$ was used to indicate the degree of differentiation between each pair of populations and the analysis of molecular variance (AMOVA) was conducted to detect the source of variations among populations in Egypt, Libya and Saudi Arabia, and within populations using allele frequencies with ARLEQUIN V. 1.1 (Excoffier et al., 1992).

Table 3. Genetic diversity for A. hierochuntica populations. $N_{a}=$ Observed number of alleles, $N_{e}=$ Effective number of Alleles, $h=$ Nei's gene diversity, $I=$ Shannon's diversity index, $P L=$ Number of polymorphic loci, $P P L=$ Percentage of polymorphic loci

\begin{tabular}{c|c|c|c|c|c|c}
\hline Country & $\boldsymbol{N}_{\boldsymbol{a}}$ & $\boldsymbol{N}_{\boldsymbol{e}}$ & $\boldsymbol{h}$ & $\boldsymbol{I}$ & $\boldsymbol{P L}$ & $\boldsymbol{P P L}$ \\
\hline Lybia & $1.933 \pm 0.258$ & $1.622 \pm 0.294$ & $0.361 \pm 0.138$ & $0.588 \pm 0.182$ & 14 & $93 \%$ \\
Egypt & $1.905 \pm 0.212$ & $1.551 \pm 0.266$ & $0.336 \pm 0.126$ & $0.506 \pm 0.169$ & 14 & $93 \%$ \\
Saudi & $1.867 \pm 0.352$ & $1.627 \pm 0.347$ & $0.352 \pm 0.170$ & $0.513 \pm 0.233$ & 13 & $86 \%$ \\
\hline
\end{tabular}

\section{Results}

\section{Genetic variation}

Ten primers generated a total of 115 RAPD bands (loci), 11.5 band per primer on the average. The number of amplification products per primer varied from 7 to 15 which produced fragments ranging from 285 to 3525 base pair in size.

Despite the resemblance in values among the three populations concerning the genetic diversity parameters, the $\mathrm{L}$ population reached the greatest values for the observed number of alleles (1.933), the Nei's gene diversity (0.361) and the Shannon's diversity index (0.588) (Table 3). The percent of polymorphic loci ranged from $86 \%$ in the $\mathrm{S}$ population to $93 \%$ in the $\mathrm{L}$ and $\mathrm{E}$ populations. The lowest values for the estimated genetic diversity parameters were recorded in the E population, while the S population attained an intermediate position.

The Shannon's diversity index and the phytomass per square meter in $A$. hierochuntica populations were found to be strongly related with an $\mathrm{R}^{2}$ of 0.99 (Figure 1). The $\mathrm{E}$ and $\mathrm{S}$ populations have low phytomass (92 and $212 \mathrm{gm}^{-2}$ respectively) as compared to $753 \mathrm{gm}^{-2}$ obtained in the L population. This is coupled with Shannon's diversity index values around 0.51 in the $\mathrm{E}$ and $\mathrm{S}$ populations as compared to 0.59 in the L population (Table 3).

Table 4. Analysis of molecular variance (AMOVA) among and within A. hierochuntica populations in Egypt, Libya and Saudi Arabia

\begin{tabular}{c|c|c|c|c|c}
\hline Source of variation & d.f. & Sum of Squares & $\begin{array}{c}\text { Variance } \\
\text { components }\end{array}$ & $\begin{array}{c}\text { Percentage } \\
\text { of variation }\end{array}$ & \\
\hline Among populations & 2 & 063.210 & 0.153 & 32.089 & $\mathrm{P}<0.000$ \\
Within populations & 1039 & 296.371 & 0.324 & 67.910 & $\mathrm{P}<0.000$ \\
Total & 1041 & 359.581 & 0.477 & & \\
\hline
\end{tabular}




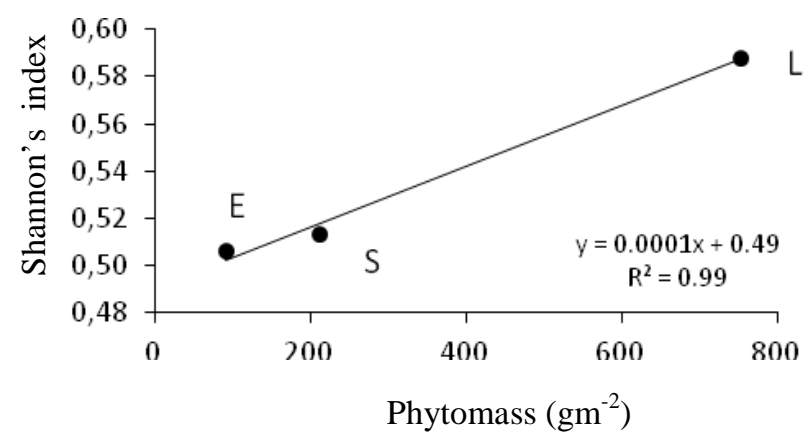

Figure 1. Relationship between the Shannon's diversity index and the phytomass per square meter among A. hierochuntica populations

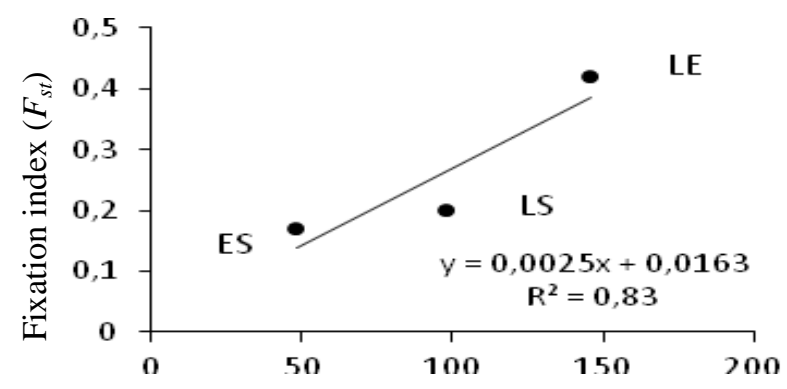

Rainfall (mm)

Figure 2. Relationship between the pairwise fixation index $F_{s t}$ and the difference in the total amount of rainfall among A. hierochuntica populations. LE: Libya and Egypt, LS: Libya and Saudi Arabia and ES: Egypt and Saudi Arabia

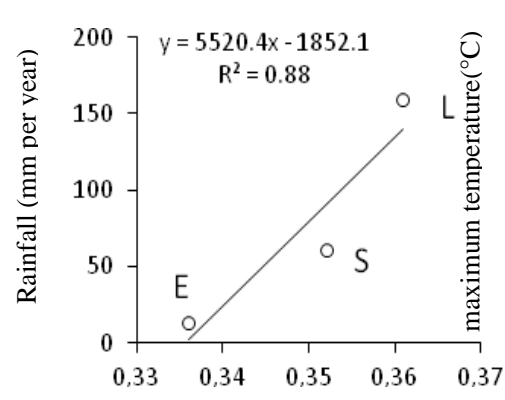

(a)

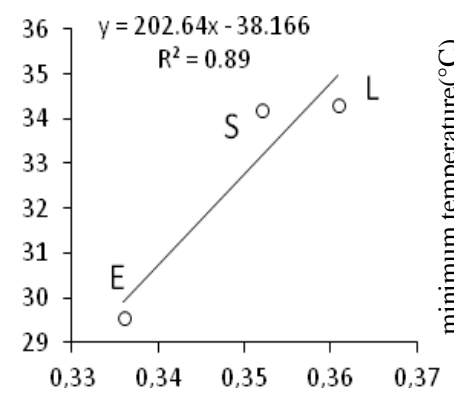

(b)

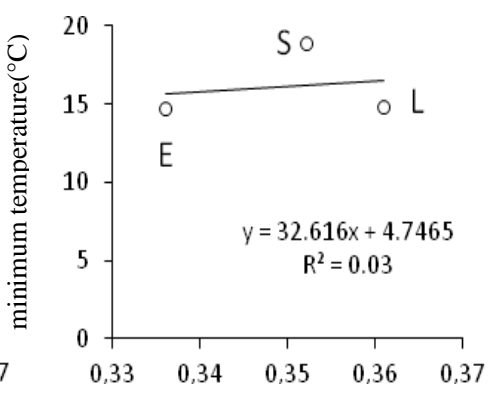

(c)

Nei's genetic diversity

Figure 3. Relationship between Nei's genetic diversity in the three A. hierochuntica populations and total annual rainfall $(a)$, mean maximum $(b)$ and mean minimum $(c)$ daily temperatures 
According to the AMOVA among and within populations, the highest percentage of variation reached $67.910 \%$ and found to be within the study populations (Table 4). The percentage of variation among the populations in L, E, and S was $32.089 \%$ of the total variance. A strong linear relationship $\left(\mathrm{R}^{2}=0.77\right)$ was obtained between the pairwise $F_{s t}$ and the difference in the total amount of rainfall between A. hierochuntica population pairs (Figure 2). The highest genetic differentiation was obtained between $\mathrm{L}$ and $\mathrm{E}$ populations $\left(F_{s t}=0.42\right.$, very high genetic differentiation) where the difference in the total amount of rainfall reached $145.93 \mathrm{~mm}$, followed by that between $\mathrm{L}$ and $\mathrm{S}$ populations $\left(F_{s t}=0.20\right.$, high genetic differentiation, $97.94 \mathrm{~mm}$ difference $)$. Alternatively, the lowest differentiation was obtained between $\mathrm{E}$ and $\mathrm{S}$ populations (47.99 mm difference) with an $F_{s t}$ value of 0.17 with high genetic differentiation.

\section{Response to environmental factors}

The relationships between the Nei's gene diversity and the amount of rainfall and the maximum temperature were more evident as compared to that with the minimum temperature (Figure 3). In this case, an increasing linear relationship was obtained $\left(\mathrm{R}^{2}=\right.$ 0.88 and 0.89 ) between the Nei's gene diversity and the amount of rainfall and the maximum temperature respectively revealing an increase in the gene diversity in sites receiving higher amounts of rainfall and higher maximum temperature.

\section{Discussion}

\section{Intrapopulation genetic variation}

The amount of genetic variation within Anastatica hierochuntica populations reached $67.910 \%$ of the total variance in the AMOVA test. Moreover, the Nei's gene diversity (ranging from 0.336 to 0.361 ) and the Shannon's diversity index (ranging from 0.506 to 0.588 ) showed relatively high values. Similar proportion of intrapopulation genetic variation were reported in other species as crataegus monogyna from northern Italy where the mean genetic diversity ranged between 0.252 and 0.333 with about $80 \%$ of the genetic variation found within populations (Ferrazzini et al., 2008). The Intrapopulation genetic diversity affects the evolutionary potential of a species and is considered as an indirect indicator of extinction risk as the loss of genetic diversity decreases the probability of persistence (Ellstrand and Elam, 1993; Allendorf and Ryman, 2002). High adaptation ability of a species to environmental conditions is generally rendered to high genetic diversity within that species (Kim et al., 2008). Even in annual plants, adaptation is prevented by a lack of genetic variation or maladaptive gene flow (Moeller et al., 2011). However, adaptive evolution is not always generated as a result of a reach genetic diversity in a species as some invasive species characterized by low within population genetic diversity evolve through a series of events after colonizing such as hybridization (Ellstrand and Schierenbeck, 2000; Xu et al., 2003; Ye et al., 2004). For many tree species, the diversity was mainly found within populations and hybridization may be a cause of this heterozygosity (Imbert and Lefèvre, 2003).

Along the range of species distribution from Libya to Saudi Arabia, the gene diversity showed a complex pattern of variation. From the West to the East the gene diversity reached maximum value in Libya, minimum value in Egypt, then increased in Saudi Arabia indicating the presence of a complex underlying environmental 
heterogeneity controlling the genetic structure of the species. In the Libya population, where the highest value of the gene diversity was obtained, the highest values for the total amount of annual rainfall and maximum temperature were recorded coupled with the highest value of phytomass per square meter. Despite the lower values of the gene diversity obtained in the Saudi Arabia then in the Egypt populations, a strong linear relationship with the total amount of annual rainfall $\left(\mathrm{R}^{2}=0.88\right)$ and the maximum temperature $\left(\mathrm{R}^{2}=0.89\right)$ was obtained. Furthermore, a strong relationship was obtained $\left(\mathrm{R}^{2}=0.85\right)$ among the three populations between the Shannon's diversity index and the phytomass per square meter. Even with little difference in the total amount of rainfall and maximum temperature between Saudi Arabia and Egypt the species showed higher phytomass and more diverse gene pool in Saudi Arabia population. This is consistent with previous studies (Hegazy and Kabiel, 2010) where A. hierochuntica proved a flexible trend sensitive to the available amount of rainfall. Also, the plant size in other species is generally positively correlated with the gene diversity (Lauterbach et al., 2012).

We suggested that $A$. hierochuntica maintains an evolutionary mechanism supported by a high intrapopulation genetic diversity that may be rendered to the persistent seed bank. This evolutionary mechanism permits the species to withstand the harsh environmental conditions in the desert ecosystem and is demonstrated by a complex pattern of minor genetic variations from Libya to Saudi Arabia and the associated variations in phytomass and seed productivity.

\section{Interpopulation genetic variation}

The interpopulation genetic differentiation in A. hierochuntica proved to be influenced by the difference in the total amount of rainfall between pairs of populations. The pairwise $\mathrm{F}_{\mathrm{st}}$ among the three study populations was found to be directly proportional to the rainfall difference $\left(\mathrm{R}^{2}=0.77\right)$ between each pair. Understanding how genetic variation shapes species' distributions involves examining how variation is distributed across a species' range as well as how it responds to underlying environmental heterogeneity (Emery et al., 2012). In the present study, the genetic differentiation pattern among A. hierochuntica populations showed the highest $\mathrm{F}_{\mathrm{st}}$ between $\mathrm{L}$ and $\mathrm{E}$. Comparatively, lower $\mathrm{F}_{\text {st }}$ was obtained between $\mathrm{L}$ and $\mathrm{S}$ populations irrespective of the geographical distance between the population pairs. At first; the relationship between $\mathrm{L}$ and $\mathrm{E}$ populations reveals the presence of partial local adaptation as $\mathrm{F}_{\mathrm{st}}$ reached 0.42 . The most obvious climatic heterogeneity lies in a more than ten folds greater total annual rainfall in $\mathrm{L}$ than in $\mathrm{E}$ populations. A comparable value $\left(\mathrm{F}_{\mathrm{st}}=0.51\right)$ was obtained among tree populations where selfing breeding system was considered to be a major cause (Hamrick et al., 1993). Similarly, high differentiation was reported among Myrtus communis L. populations ( $\mathrm{F}_{\mathrm{st}}$ reached 0.41) and was related to the heterogeneity in climatic conditions and to the geographic distance (Emery et al., 2012). Similarly, the relationship between S and E showed high $F_{\text {st }}$ value (0.17) with more than four times greater total annual rainfall in $S$ than in $E$ populations. However, the maximum temperature in $S$ was recorded to be higher by about five degrees than in E populations. Second; the relationship between L and $S$ populations showed lowest $\mathrm{F}_{\mathrm{st}}$ value $(0.20)$ where these populations are the most distant with a difference in the total annual rainfall reaching more than the double of its value in $\mathrm{L}$ than in $\mathrm{S}$ and similar maximum temperature. 
In hydrochoric species, Fst may reach 0.5 revealing high genetic differentiation among populations (Liu et al., 2006). Habitat fragmentation or historical isolation is also predicted to increase divergence among populations (Young et al., 1996). The tendency toward larger divergence with a larger geographical distance between populations was reported in the Turkish endemic perennial species Centaurea wiedemanniana, inhabiting rocky slopes and characterized by limited seed dispersal, where the pairwise $\mathrm{F}_{\mathrm{st}}$ values was correlated to the pairwise geographical distance (Sozen and Ozaydin, 2010).Obviously, in the present study, the role of the difference in the geographical distance among A. hierochuntica populations is not important by itself but the resulting habitat heterogeneity where many environmental variables are interfering and the most powerful of them is the total annual rainfall. In general, habitat heterogeneity created by the large separation distances among populations might be responsible for a large part of the interpopulation genetic differentiation.

\section{Dispersal strategy and genetic variation}

The variations of the genetic diversity and structure of many species was rendered to the dispersal mode especially who's dispersed by hydrochory (Gibson and Wheelwright, 1995; Lundqvist and Anderson, 2001; Imbert and Lefèvre, 2003; Liu et al., 2006). The pattern of the genetic variation in A. hierochuntica populations is shaped by the amount of rainfall which in turn affects the seed dispersal (Hegazy and Kabiel, 2007). Hydrochory may increase genetic diversity in populations by receiving dispersed seeds by water sheets (Nilsson et al., 2010). Great amounts of rainfall results in extensive seed dispersal through water sheets and runoff maximizing gene flow among A. hierochuntica population which decreases the genetic differentiation. On the other hand, low rainfall resulted in limited seed dispersal around the mother plant creating an adaptation of the genetic system to small population conditions and a restricted gene flow rate which increase genetic differentiation among populations. Limited seed dispersal and/or habitat heterogeneity was reported to account for high levels of genetic differentiation among plant populations (Sozen and Ozaydin, 2010; Li et al., 2008). In this case, the harsh environmental conditions and / or habitat fragmentation are compensated by a unique dispersal system controlling the overall genetic diversity of the species. The presence of a canopy seed bank ensure the prevention of a genetic drift to occur as a permanent supply of seed is present and ready to germinate in favorable conditions. Persistent seed bank was supposed to mitigate the consequences of habitat fragmentation and protect a species from genetic drift (Van Oudtshoorn and Van Rooyen, 1999), especially for extreme desert plants inhabiting small separate patches or depressions (Gutterman, 1994). High rainfall even every several years will ensure the production of canopy seed bank with more diverse gene pool. This seed bank may compensate the low rainfall for several coming years resulting in small population size with low genetic diversity. Consequently, relatively high gene diversity was found in the Egypt population characterized by the lowest amount of rainfall and habitat disturbance, due to overcollection and destruction of the natural habitats, which resulted in reduced fitness as demonstrated by the low amount of phytomass per square meter. This contrasted other plant species where genetic drift and reduced plant size were expected as a direct result for habitat disturbance and fragmentation which increase genetic differentiation among populations (Harrison and Hastings, 1996; Honnay et al., 2007; Yang et al., 2010; Lauterbach et al., 2012). Fragmentation was found to be more effective in increasing genetic differentiation among riparian tree populations-mainly 
dispersed by water-than the physical barriers as it alters the natural dynamics of the ecosystem (Imbert and Lefèvre, 2003). However, high gene diversity in small populations was reported by Honnay et al. (2007).

The amount of rainfall control the mode of seed dispersal, particularly, short distance dispersal around the mother plant increasing genetic differentiation among populations or long distance dispersal decreasing differentiation among populations. In both cases, the hydrochoric mode of seed dispersal together with the presence of persistent canopy seed bank ensures relatively high intrapopulation gene diversity even in highly fragmented populations.

\section{Conclusions}

Anastatica hierochuntica proved to be an annual plant with a perennial performance. As generally, perennial and outcrossing species retain most of their genetic variability within populations while annual and selfing species allocate most of the genetic variability among population. Then, the presence of a persistent canopy seed bank in an annual plant preserves a reach multigenerational gene pool and provides the study species with a permanent supply of seeds from the same source as in perennials. Moreover, this maintains high intrapopulation genetic diversity and may buffer the decrease in the genetic diversity in extremely dry years where small populations were expected to grow increasing the opportunity for possible genetic drift. In this case, low amounts of rainfall allowed small number of seeds to germinate resulting in small number of individuals for several consecutive years. Without the supply of seeds from the canopy seed bank the population may be subjected to genetic drift.

Both the genetic diversity within populations and the genetic differentiation among populations are closely related to the total annual rainfall which governs the whole dispersal strategy of the species. Individuals of A. hierochuntica profit from favourable climatic conditions in favourable years to produce greater phytomass i.e. bigger canopy seed bank and larger amounts of seeds (Hegazy and Kabiel, 2010). The species creates larger supply of seeds as possible to be used in subsequent years. Hence, our study proves that the larger the canopy seed bank (in the Libya population) the greater the within population genetic diversity and the smaller the canopy seed bank (in the Egypt population) the lower the within population genetic diversity. In this case, high differentiation was observed between the E population and both $\mathrm{L}$ and $\mathrm{S}$ populations. The canopy seed bank in A. hierochuntica may have great significance in the context of species evolution and conservation of genetic diversity of the species. In fact, the canopy seed banks from several individuals in a population are created through years resulting in intergenerational genetic diversity.

\section{REFERENCES}

[1] Allendorf, F., Ryman, N. (2002): The role of genetics in population viability analysis. In Population Viability Analysis, Beissinger, S.R., McCullough, D.R. (eds), University of Chicago Press, 593 pp.

[2] Boulos, L. (1983): Medicinal Plants of North Africa. - In the series: "Medicinal Plants of the World", Reference Publication, Inc. Michigan, USA, 286 pp. 
[3] Cabin, R.J., Mitchell, R.J., Marshall, D.I. (1998): Do surface plant and soil seed bank populations differ genetically? A multipopulation study of the desert mustard Lesquerella fendleri (Brassicaceae). - American Journal of Botany 85: 1098-1109.

[4] Ellstrand, N.C., Elam, D.R. (1993): Population genetic consequences of small population size. Implications for plant conservation. - Annual Review of Ecology and Systematics 24: $217-242$.

[5] Ellstrand, N.C., Schierenbeck, K.A. (2000): Hybridization as a stimulus for the evolution of invasiveness in plants? - In: Proceedings of the National Academy of Sciences of the USA, Washington, DC, USA, pp. 7043-7050.

[6] Emery, N.C., Rice, K.J., Stanton, M.L. (2012): Fitness variation and local distribution limits in an annual plant population. - Evolution 65: 1011-1020.

[7] Evenari, M., Shanan, L., Tadmor, N. (1982): The Negev. The challenge of a Desert. 2nd edition. - Cambridge, M. A., Harvard Univ. Press. 345 pp.

[8] Excoffier, L., Laval, G., Schneider, S. (1992): Arlequin ver. 3.0: an integrated software package for population genetics data analysis. - Evolutionary Bioinformatics 1: 47-50.

[9] Ferrazzini, D., Monteleone, I., Belletti, P. (2008): Small-scale genetic diversity in one seed hawthorn (Crataegus monogyna jacq.). - European Journal of Forest Research 127: 407-414.

[10] Friedman, J., Gunderman, N., Ellis, M. (1978): Water response of the hygrochastic skeletons of the true rose of Jericho (Anastatica hierochuntica L.). - Oecologia 32: 289301.

[11] Gibson, J.P., Wheelwright, N.T. (1995): Genetic structure in a population of a tropical tree Ocotea tenera (Lauraceae): influence of avian seed dispersal. - Oecologia 103: 4954.

[12] Gutterman, Y. (1994): Strategies of Seed Dispersal and Germination in Plants Inhabiting Deserts. - The Botanical Review 60: 373-425.

[13] Hamrick, J.L., Murawski, D.A., Nason, J.D. (1993). The influence of seed dispersal mechanisms on the genetic structure of tropical tree populations. - Vegetatio 107/108: 281-297.

[14] Harrison, S., Hastings, A. (1996): Genetic and evolutionary consequences of metapopulation structure. - Trends in Ecology and Evolution 11: 180-183.

[15] Hegazy, A.K. (1990): Growth, phenology, competition and conservation of two desert hygrochastic annuals raised under different watering regimes. - Journal of Arid Environments 19: 85-94.

[16] Hegazy, A.K., Barakat, H.N., Kabiel, H.F. (2006): Anatomical significance of the hygrochastic movement in Anastatica hierochuntica. - Annals of Botany 97: 47-55.

[17] Hegazy, A.K., Kabiel, H.F. (2007): Significance of microhabitat heterogeneity in the spatial pattern and size-class structure of Anastatica hierochuntica L. - Acta oecologica 31: 332-342.

[18] Hegazy, A.K., Kabiel, H.F. (2010): Size-class structure and growth traits of Anastatica hierochuntica L. populations as rainfall indicators in aridlands. - Journal of Advanced Research 1: 331-340.

[19] Honnay, O., Adriaens, D., Coart, E., Jacquemyn, H., Roldan-Ruiz, I. (2007): Genetic diversity within and between remnant populations of the endangered calcareous grassland plant Globularia bisnagarica L. - Conservation Genetics 8: 293-303.

[20] Honnay, O., Bossuyt, B., Jacquemyn, H., Shimono, A., Uchiyama, K. (2008): Can a seed bank maintain the genetic variation in the above ground plant population? - Oikos 117: 15.

[21] Imbert, E., Lefèvre, F. (2003): Dispersal and gene flow of Populus nigra (Salicaceae) along a dynamic river system. - Journal of Ecology 91: 447-456.

[22] Imbert, E., Lefèvre, F. (2003): Dispersal and gene flow of Populus nigra (Salicaceae) along a dynamic river system. - Journal of Ecology 91: 447-456. 
[23] Kim, C., Na, H.R., Choi, H.-K. (2008): Conservation genetics of endangered Brasenia schreberi based on RAPD and AFLP markers. - Journal of Plant Biology 51: 260-268.

[24] Lauterbach, D., Ristow, M., Gemeinholzer, B. (2012): Population genetics and fitness in fragmented populations of the dioecious and endangered Silene otites (Caryophyllaceae). - Plant Systematics and Evolution 298: 155-164.

[25] Lauterbach, D., Ristow, M., Gemeinholzer, B. (2012): Population genetics and fitness in fragmented populations of the dioecious and endangered Silene otites (Caryophyllaceae). - Plant Systematics and Evolution 298: 155-164.

[26] Li, J., Jin, Z., Lou, W., Li, J. (2008): Genetic diversity of Lithocarpus harlandii populations in three forest communities with different succession stages. - Frontiers of Forestry in China 3: 106-111.

[27] Liu, Y., Wang, Y., Huang, H. (2006): High interpopulation genetic differentiation and unidirectional linear migration patterns in Myricaria laxiflora (tamaricaceae), an endemic riparian plant in the Three Gorges Valley of the Yangtze River. - American Journal of Botany 93: 206-215.

[28] Liu, Y., Wang, Y., Huang, H. (2006): High interpopulation genetic differentiation and unidirectional linear migration patterns in Myricaria laxiflora (tamaricaceae), an endemic riparian plant in the Three Gorges Valley of the Yangtze River. - American Journal of Botany 93: 206-215.

[29] Lundqvist, E., Anderson, E. (2001): Genetic diversity in populations of plants with different breeding and dispersal strategies in a free-flowing boreal river system.Hereditas 135: 75-83.

[30] Messaouda, C., Afifa, M., Boulilaa, A., Rejebb, M., Boussaida, M. (2007): Genetic variation of Tunisian Myrtus communis L. (Myrtaceae) populations assessed by isozymes and RAPDs. - Annals of Forest Science 64: 845-853.

[31] Moeller, D.A., Geber, M.A., Tiffin, P. (2011): Population Genetics and the Evolution of Geographic Range Limits in an Annual Plant. - The American Naturalist 178: 44-57.

[32] Nilsson, C., Brown, R.L., Jansson, R., Merritt, D.M. (2010): The role of hydrochory in structuring riparian and wetland vegetation. - Biological Reviews 85: 837-858.

[33] Nyboma, H., Bartish, I.V. (2000): Effects of life history traits and sampling strategies on genetic diversity estimates obtained with RAPD markers in plants. - Perspectives in Plant Ecology, Evolution and Systematics 3: 93-114.

[34] Ouborg, N.J., Piquot, Y., Van Groenendael, J.M. (1999): Population genetics, molecular markers and the study of dispersal in plants. - Journal of Ecology 87: 551-568.

[35] Reed, D.H., Frankham, R. (2003): Correlation between Fitness and Genetic Diversity. Conservation Biology 17: 230-237.

[36] Sozen, E., Ozaydin, B. (2010): A Study of Genetic Variation in Endemic Plant Centaurea wiedemanniana by Using RAPD Markers. - Ekoloji 77: 1-8.

[37] Van Oudtshoorn, R.K., Van Rooyen, M.W. (1999): Dispersal Biology of Desert Plants. Springer-Verlag, Germany, $241 \mathrm{pp}$.

[38] Vellend, M., Geber, M.A. (2005): Connections between species diversity and genetic diversity. - Ecology Letters 8: 767-781.

[39] Venable, D.L., Lawlor, L. (1980): Delayed Germination and Dispersal in Desert Annuals: Escape in Space and Time. - Oecologia 46: 272-282.

[40] Xu, C.Y., Zhang, W.J., Fu, C.A., Lu, B.R. (2003): Genetic diversity of alligator weed in China by RAPD analysis. - Biodiversity and Conservation 12: 637-645.

[41] Yang, S., Lu, X., Ye, R., Li, Y., Zhou, Y., Yue, P., Zhao, J., Zhang, C., Peng, M. (2010): Genetic diversity and population structure in Meconopsis quintuplinervia (Papaveraceae). - African Journal of Biotechnology 9: 3048-3053.

[42] Ye, W.H., Mu, H.P., Cao, H.L., GE, X.J. (2004): Genetic structure of the invasive Chromolaena odorata in China. - Weed Research 44: 129-135. 
[43] Yeh, F.C., Yang, R.-C., Boyle,T., Ye, Z.-H., Mao, J.X. (1997): POPGENE: the userfriendly shareware for population genetic analysis. - Molecular Biology and Biotechnology Centre, University of Alberta, Canada.

[44] Young, A., Boyle, T., Brown, T. (1996): The population genetic consequences of habitat fragmentation for plants. - Tree 11: 413-418. 